\title{
Review
}

\section{Endocrine Effects of Inhaled Corticosteroids in Children}

Chirag R. Kapadia, MD; Todd D. Nebesio, MD; Susan E. Myers, MD; Steven Willi, MD; Bradley S. Miller, MD, PhD; David B. Allen, MD; Elka Jacobson-Dickman, MD; for the Drugs and Therapeutics Committee of the Pediatric Endocrine Society

Inhaled corticosteroids (ICSs) are widely used as first-line treatment for various chronic respiratory illnesses. Advances in devices and formulations have reduced their local adverse effects. However, as delivery of ICSs to the lungs improves, the systemic absorption increases, and an adverse effect profile similar to, although milder than, oral corticosteroids has emerged. The most serious potential adverse effect is adrenal insufficiency, which can be life threatening. Adrenal insufficiency occurs most in patients taking the highest doses of ICSs but is reported with moderate or even low doses as well. Our recommendations include greater vigilance in testing adrenal function than current standard practice. In patients with diabetes mellitus (types 1 and 2), an increase in glucose levels is likely, and diabetes medication adjustment may be needed when initiating or increasing ICSs. The risk of linear growth attenuation and adverse effects on bone mineral density is generally low but should be considered in the face of additional risk factors. On behalf of the Pediatric Endocrine Society Drugs and Therapeutics Committee, we present a review of the endocrine adverse effects of ICSs in children and offer recommendations relating to testing and referral. Limited data in particular realms diminish the strength of certain recommendations, and clinical judgment continues to be paramount.

JAMA Pediatr. 2016;170(2):163-170. doi:10.1001/jamapediatrics.2015.3526 Published online December 21, 2015.

\author{
Author Affiliations: Author \\ affiliations are listed at the end of this \\ article. \\ Group Information: The members of \\ the Drugs and Therapeutics \\ Committee of the Pediatric Endocrine \\ Society are listed at the end of this \\ article. \\ Corresponding Author: Elka \\ Jacobson-Dickman, MD, Division of \\ Pediatric Endocrinology, Department \\ of Pediatrics, Maimonides Medical \\ Center, 4802 10th Ave, Brooklyn, NY \\ 11219 (ejacobson-dickman \\ @maimonidesmed.org).
}

I nhaled corticosteroids are widely used as effective first-line treatments for various chronic respiratory illnesses, including asthma, cystic fibrosis, and allergic rhinitis. ${ }^{1}$ Although the long-term use of ICSs has a more favorable safety profile than oral corticosteroids, uncertainty about systemic complications persist. In children, the long-term use of oral corticosteroids can lead to compromised linear growth and bone mineralization, diabetes mellitus (types 1 and 2) (DM), Cushing syndrome, obesity, and suppression of the hypothalamic-pituitary-adrenal (HPA) axis. Inhaled corticosteroids have a similar adverse effect profile but with less frequency and severity. We review the endocrine effects of ICSs in children and the properties of the various formulations as they relate to these adverse outcomes. We have provided grading of the evidence associated with our conclusions and recommendations based on guidelines from the Centre for Evidence Based Medicine, in which a lower number indicates better evidence (scale, 1-5), and $A$ is the highest grade of recommendation (scale, A-D) ${ }^{2}$

\section{Case Presentation}

A 7-year-old girl presented with altered mental status and a newonset seizure. She was well until that day, when she developed cough, fatigue, and fever and then had a generalized seizure. When the ambulance arrived, her blood glucose level was 24 $\mathrm{mg} / \mathrm{dL}$ (to convert to millimoles per liter, multiply by 0.0555 ). In the emergency department, her blood pressure was $85 / 50 \mathrm{~mm}$
$\mathrm{Hg}$, and her pulse was $125 / \mathrm{min}$. The results of head imaging and a full sepsis workup were normal. Her medical history was significant for asthma and seasonal allergies. At home she took a regimen of fluticasone propionate dry powder inhaler (two 110- $\mu \mathrm{g}$ puffs twice daily), salmeterol xinafoate $(21 \mu \mathrm{g} / \mathrm{d})$, albuterol sulfate as needed, and cetirizine $(10 \mathrm{mg} / \mathrm{d})$ to which she was adherent. She had a 5-day course of prednisone 4 months prior. Her growth was normal.

She had a sodium level of $140 \mathrm{mEq} / \mathrm{L}$ (to convert to millimoles per liter, multiply by 1), and her potassium level was $4 \mathrm{mEq} / \mathrm{L}$ (to convert to millimoles per liter, multiply by 1$)$. A serum cortisol level at the time of the hypoglycemia was low $(2.1 \mu \mathrm{g} / \mathrm{dL}$ ) (to convert to nanomoles per liter, multiply by 27.588). Further testing revealed a morning cortisol level of $0.8 \mu \mathrm{g} / \mathrm{dL}$ and an adrenocorticotropic hormone (ACTH) level less than $5 \mathrm{pg} / \mathrm{mL}$ (to convert to picomoles per liter, multiply by 0.22), suggesting central adrenal insufficiency (AI). A low-dose 1- $\mu$ g ACTH stimulation test confirmed Al with a peak cortisol level of $1.4 \mu \mathrm{g} / \mathrm{dL}$ (reference range, $>18 \mu \mathrm{g} / \mathrm{dL}$ ). Thyroid function test results, insulin-like growth factor 1 (IGF-1) levels, and prolactin levels were normal. Maintenance hydrocortisone treatment was initiated, and the family received stress dose corticosteroid education. Her pulmonologist reduced the inhaled corticosteroid (ICS) dose to $330 \mu \mathrm{g} / \mathrm{d}$ after adding montelukast, and the asthma remained well controlled. The hydrocortisone dose was gradually weaned and hydrocortisone use discontinued. Six months later, an additional low-dose ACTH stimulation test result was normal with a peak stimulated cortisol level of $19.9 \mu \mathrm{g} / \mathrm{dL}$. The HPA axis suppression was attributed to her ICSs. 


\section{Dose and Formulation Effects of ICSs}

\section{Primary Conclusions}

Clinical effectiveness and systemic absorption have a strong positive correlation that can only be partially addressed by device and formulation modifications (level of evidence 1).

\section{Primary Recommendations}

Device advancements have reduced local adverse effects. However, reducing the systemic adverse effects of ICSs may require increasing protein binding and rapid clearance time and decreased lipophilicity (grade of recommendation A).

Pharmacodynamics and pharmacokinetics vary among ICS formulations. This is a result of differences in oral bioavailability, glucocorticoid receptor affinity, variable deposition in the lung, volumes of distribution, lipophilic qualities, rates of clearance, and modes of delivery. ${ }^{1,3}$

There are a variety of ICS delivery devices, including metereddose inhalers, dry powder inhalers, and nebulizers; metered-dose inhalers are often used with spacer devices that reduce oral deposition and increase lung delivery. Oral deposition and lung delivery are also affected by particle size, with smaller particles having less oral and greater lung deposition. ${ }^{4}$ Local adverse effects, such as candidiasis, dysphonia, pharyngitis, and cough, are minimized with proper inhalation technique and postinhalation oropharyngeal rinsing. Compounds with a high rate of first-pass metabolism have less systemic drug effect from oral deposition than those with lower rates. ${ }^{5}$

The clinically efficacious ICS deposited in the lung is also the main source for systemic absorption ${ }^{5,6}$; therefore, improved lung delivery of ICS actually increases the risk of endocrine adverse effects. Although the shift from chlorofluorocarbons to hydrofluoroalkane allows smaller particle sizes and better lung delivery for many compounds, it can also result in greater systemic absorption. ${ }^{7}$

There are variable degrees of cortisol suppression or systemic bioavailability among delivery devices ${ }^{8-10}$; however, for most ICSs, respiratory effectiveness correlates with systemic bioavailability. Devices that result in greater lung deposition should thus be used at lower doses. Postulation regarding the effect of discrepant intralung absorption has arisen, for example, whether there is greater systemic absorption from alveoli than bronchi, but data in this area are lacking. ${ }^{4}$ What appears clear, however, is that in healthy lungs or healthier asthmatic lungs, absorption is greater than in states of active disease and airflow obstruction, hence supporting clinical guidelines advocating step-down therapy for those who achieve asthma control. ${ }^{11,12}$

Compounds or metabolites that are more tightly bound to albumin and other proteins and less systemically active have fewer adverse effects, as do those cleared from the circulation more rap-

\section{At a Glance}

- Inhaled corticosteroids (ICSs) are widely used as effective first-line treatment for various chronic respiratory illnesses. Although the long-term use of ICSs has a more favorable safety profile than that of oral corticosteroids, uncertainty about systemic complications persists.

- With the advancement of devices and in drug pharmacokinetics, lung delivery and bioavailability of ICSs have improved, and an adverse effect profile similar to oral corticosteroids is emerging, albeit milder and with less frequency.

- Hypothalamic-pituitary-adrenal axis suppression is a potentially life-threatening adverse effect of ICSs. Adrenal function should be tested in symptomatic patients, those with growth attenuation, and high-risk asymptomatic patients.

- Data on linear growth and bone mineral density (BMD) are generally reassuring, but height attainment should be carefully monitored, and testing for BMD should be considered in high-risk patients. Deteriorating blood glucose level control in patients with preexisting diabetes mellitus (types 1 and 2) (DM) is common with ICSs, and DM medication dose adjustments are likely required at the initiation of ICS treatment and with ICS dose increases.

idly. Although not well investigated, some experts ${ }^{13}$ assert that increased lipophilicity leads to greater systemic adverse effects because of wider distribution and slower clearance, particularly in the case of fluticasone. Thus, although efforts to reduce oral deposition have resulted in fewer local adverse effects, the effort to reduce systemic adverse effects may ultimately need to focus on increasing protein binding, more rapid clearance, and decreasing lipophilicity. Binding and clearance data for commonly used ICSs are summarized in Table $1 .^{14}$

The compound ciclesonide hydrofluoralkane ${ }^{14}$ is converted to a metabolite that has a high first-pass metabolism rate, is highly protein bound, is rapidly cleared, and thus would be expected to deliver clinical effect at the lungs while resulting in lower systemic consequence. However, experience with ciclesonide is not as long standing or as widespread as with fluticasone proprionate dry powder inhaler, and it took many years of clinical use for endocrine adverse effects of fluticasone to surface. ${ }^{13-15}$ Thus, although the pharmacodynamic profile of ciclesonide appears to be promising, cautious optimism is recommended.

\section{Effects on the HPA Axis}

\section{Primary Conclusions}

The HPA axis suppression, although rare, is the most serious potential ICS adverse effect and can occur even in children taking standard dosages (level of evidence 1).

\begin{tabular}{lcccc}
\hline \multicolumn{1}{l}{ Table 1. Pharmacodynamics and Pharmacokinetics of Commonly Used Inhaled Glucocorticoid Formulations } \\
\hline Inhaled Glucocorticoid & $\begin{array}{l}\text { Oral } \\
\text { Bioavailability, } \%\end{array}$ & $\begin{array}{l}\text { Particle } \\
\text { Size, } \mu \mathrm{m}\end{array}$ & $\begin{array}{l}\text { Protein } \\
\text { Binding, } \%\end{array}$ & $\begin{array}{l}\text { Systemic } \\
\text { Clearance, L/h }\end{array}$ \\
\hline Beclomethasone dipropionate hydrofluoroalkane & $20 / 40^{\mathrm{b}}$ & $<2.0$ & 87 & $150 / 120^{\mathrm{b}}$ \\
\hline Budesonide DPI & 11 & $>2.5$ & 88 & 84 \\
\hline Ciclesonide hydrofluoroalkane & $<1 /<1^{\mathrm{b}}$ & $<2.0$ & $99 / 99^{\mathrm{b}}$ & $152 / 228^{\mathrm{b}}$ \\
\hline Fluticasone propionate DPI & $\leq 1$ & 2.8 & 90 & 66 \\
\hline
\end{tabular}

Abbreviation: DPI, dry powder inhaler.

${ }^{\text {a }}$ Adapted from Ahmet et al. ${ }^{14}$

${ }^{\mathrm{b}}$ Active metabolite. 


\begin{tabular}{|c|c|c|c|c|}
\hline Adverse Effect & $\begin{array}{l}\text { Patients at } \\
\text { Highest Risk }\end{array}$ & Signs and Symptoms & Testing and Action & $\begin{array}{l}\text { Test Result } \\
\text { Interpretation }\end{array}$ \\
\hline Growth suppression & $\begin{array}{l}\text { All patients taking } \\
\text { ICSs and additional } \\
\text { growth-impairing } \\
\text { medications }\end{array}$ & $\begin{array}{l}\text { Decrease of }>2 \text { SDs in } \\
\text { height or retarded } \\
\text { growth velocity } \\
\text { below age and } \\
\text { pubertal norms } \\
\text { (persisting after } \\
1 \text { year of therapy) }\end{array}$ & Refer to a specialist & Not applicable \\
\hline Adrenal insufficiency & $\begin{array}{l}\text { Symptomatic } \\
\text { patients And } \\
\text { asymptomatic } \\
\text { patients with risk } \\
\text { factors: high daily } \\
\text { dose, taking an } \\
\text { ICS and another } \\
\text { corticosteroid, or } \\
\text { low BMI }\end{array}$ & $\begin{array}{l}\text { Cushingoid features, } \\
\text { anorexia, weight } \\
\text { loss, fatigue, growth } \\
\text { failure, or } \\
\text { hypoglycemia; } \\
\text { typical symptoms of } \\
\text { chronic adrenal } \\
\text { insufficiency may not } \\
\text { occur; hence, also } \\
\text { test all high-risk } \\
\text { asymptomatic } \\
\text { patients }\end{array}$ & $\begin{array}{l}\text { Symptomatic: if } \\
\text { morning cortisol level } \\
<3 \mu \mathrm{g} / \mathrm{dL} \text {, adrenal } \\
\text { insufficiency is likely; } \\
\text { if morning cortisol level } \\
\geq 3 \mu \mathrm{g} / \mathrm{dL}, 1-\mu \mathrm{g} \text { ACTH } \\
\text { stimulation test } \\
\text { Asymptomatic but at } \\
\text { high risk: if morning } \\
\text { cortisol level <3 } \mu \mathrm{g} / \mathrm{dL} \text {, } \\
1-\mu \mathrm{g} \text { ACTH stimulation } \\
\text { test; if morning cortisol } \\
\text { level } 3-10 \mu \mathrm{g} / \mathrm{dL}, \text { refer } \\
\text { to a specialist }\end{array}$ & $\begin{array}{l}\text { A stimulated cortisol } \\
\text { value }<18 \mu \mathrm{g} / \mathrm{dL} \text { is } \\
\text { abnormal }\end{array}$ \\
\hline $\begin{array}{l}\text { Hyperglycemia or } \\
\text { diabetes mellitus } \\
\text { (types } 1 \text { and } 2 \text { ) }\end{array}$ & $\begin{array}{l}\text { Patients with risk } \\
\text { factors or signs of } \\
\text { insulin resistance } \\
\text { taking high daily } \\
\text { dose }\end{array}$ & Polyuria, polydipsia & $\begin{array}{l}\text { Annual hemoglobin } A_{1 c} \\
\text { levels and fasting } \\
\text { glucose }\end{array}$ & $\begin{array}{l}\text { Refer to a specialist } \\
\text { if hemoglobin } A_{1 c} \\
\geq 6.0 \% \text { or fasting } \\
\text { glucose }>100 \mathrm{mg} / \mathrm{dL}\end{array}$ \\
\hline $\begin{array}{l}\text { Worsening blood } \\
\text { glucose level control } \\
\text { in diabetes mellitus } \\
\text { (types } 1 \text { and } 2 \text { ) }\end{array}$ & $\begin{array}{l}\text { Patients with } \\
\text { diabetes mellitus } \\
\text { after ICS treatment } \\
\text { is initiated or if dose } \\
\text { is increase }\end{array}$ & $\begin{array}{l}\text { Worsening blood } \\
\text { glucose control }\end{array}$ & $\begin{array}{l}\text { Adjust diabetes } \\
\text { medications }\end{array}$ & Not applicable \\
\hline $\begin{array}{l}\text { Decrease in bone } \\
\text { mineral density }\end{array}$ & $\begin{array}{l}\text { Chronic disease, } \\
\text { malnutrition, or } \\
\text { taking long-term } \\
\text { medications that } \\
\text { reduce bone mineral } \\
\text { density }\end{array}$ & $\begin{array}{l}\text { Generally } \\
\text { asymptomatic }\end{array}$ & $\begin{array}{l}\text { No routine testing } \\
\text { unless at high risk; } \\
\text { if not at high risk, } \\
400-\text { to } 800-\text {-IU vitamin } \\
\text { D supplementation and } \\
\text { ensure adequate } \\
\text { calcium intake }\end{array}$ & $\begin{array}{l}\text { Higher-dose vitamin D } \\
\text { supplementation for } \\
\text { levels }<30 \mathrm{ng} / \mathrm{mL}\end{array}$ \\
\hline
\end{tabular}

Abbreviations: ACTH, adrenocorticotropin hormone; BMI, body mass index; ICS, inhaled corticosteroid.

SI conversion factors: To convert cortisol to nanomoles per liter, multiply by 27.588 ; glucose to millimoles per liter, multiply by 0.0555 ; vitamin D

(25-hydroxyvitamin D) to nanomoles per liter, multiply by 2.496 .

a Morning cortisol level is defined as a serum cortisol level measured between 7 and 9 AM.
Primary Recommendations

Children taking ICSs with hypoglycemia or altered mental status should be urgently evaluated for adrenal insufficiency and treated, if necessary (grade of recommendation $A$ ). Children with growth failure, anorexia, or weight loss should be tested for Al (grade of recommendation B). Children taking high-dose ICSs or those requiring periodic oral corticosteroids treatment or additional long-term intranasal corticosteroid treatment, especially in conjunction with a low body mass index (BMI) (calculated as weight in kilograms divided by height in meters squared), should be tested routinely (grade of recommendation $\mathrm{C}$ ).

A testing algorithm is outlined in Table 2 and described in the text below. Stimulation testing interpretation is level of evidence $1 b$, as is making a diagnosis of Al from a morning cortisol level less than $3 \mu \mathrm{g} / \mathrm{dL}$ in a symptomatic patient.

Assurance of adrenal sufficiency in asymptomatic patients with a morning cortisol level greater than $10 \mu \mathrm{g} / \mathrm{dL}$ is level of evidence 5 , expert opinion. Thus, if suspicion is high, one should not rely solely on adequate morning cortisol values.

It is well known that oral and injectable corticosteroids can result in suppression of the HPA axis and with prolonged use can lead to adrenocortical atrophy. After the introduction of corticosteroids in the late 1940s to treat rheumatoid arthritis, reports of sudden deaths after surgery began to emerge. ${ }^{16}$ When ICSs were introduced for asthma control, HPA axis suppression was thought to be rare but still a consideration when used at high doses for a prolonged period. ${ }^{17,18}$ Reassuring studies ${ }^{19,20}$ did not have evidence of Al at standard doses of ICSs.
In a meta-analysis ${ }^{21}$ examining the adverse effects of ICSs, no evidence of Al with ICS doses at $400 \mu \mathrm{g} / \mathrm{d}$ or less was found, regardless of the drug. At higher doses, the risk of Al was increased ${ }^{17,18,21}$ and common when growth suppression was also present. ${ }^{13,22}$

Since then, however, there have also been reports of Al occurring even at lower doses. Patel et al $^{22}$ described 8 children who presented with Al despite 7 of these children being prescribed a standard recommended dose of ICS. Two presented with hypoglycemia, both without a history of abrupt cessation of ICS or illness; several children also had poor weight gain. ${ }^{13,22}$ In another case, a 7-yearold boy who presented in an acute adrenal crisis had been treated with fluticasone at a typically prescribed dose of $220 \mu \mathrm{g} / \mathrm{d}$ for several years. ${ }^{13}$

As cases of Al associated with ICSs became increasingly reported, a survey was sent to pediatricians and endocrinologists in the United Kingdom to investigate the frequency of acute adrenal crises with ICS use. ${ }^{13}$ Thirty-three patients ( 28 children) were identified: 23 patients presented with hypoglycemia, including 13 with decreased level of consciousness or coma and 9 with coma and seizures ( 1 with coma and seizure later died). Most cases involved highdose ICSs that were still within recommended guidelines for severe persistent asthma. ${ }^{13}$ In a similar survey from France, 46 patients with Al were identified, of whom $18 \%$ were not receiving highdose ICSs. ${ }^{23}$

It is important to acknowledge the lack of testing standardization across studies. ${ }^{24}$ In cases of secondary or central Al from exogenous corticosteroid use, the adrenal cortex lags behind the pituitary gland in the recovery process. ${ }^{25}$ Therefore, although a basal 
cortisol level may be normal in a child treated with an ICS, it does not ensure a sufficient cortisol increase in the setting of stress or illness. ${ }^{26}$ The lack of uniform testing for Al has resulted in inconsistent and conflicting conclusions. ${ }^{26}$

In accordance with these concerns, Zöllner ${ }^{27}$ searched the literature for studies of children treated with ICSs who were tested for Al with dynamic adrenal function test results. Only 4 studies were identified. ${ }^{19,28-30}$ Using dynamic adrenal testing, those studies sought to determine the prevalence of HPA axis suppression in 26 children with asthma treated with ICSs and intranasal corticosteroids. ${ }^{31}$ With hypocortisolemia defined as a basal morning cortisol level less than $3 \mu \mathrm{g} / \mathrm{dL}$, none of the children had a low basal cortisol level. However, metyrapone testing revealed that $35 \%$ had HPA axis suppression; this test is now difficult to perform because of the unavailability of this agent. A larger study ${ }^{32}$ by the same group found that $6 \%$ had hypocortisolemia, the degree of biochemical suppression can occur in up to two-thirds of children treated with corticosteroids, and suppression may even occur at low doses. An older study ${ }^{29}$ identified a morning ACTH level less than $11.7 \mathrm{pg} / \mathrm{mL}$ to correlate with Al on stimulation testing, but larger studies ${ }^{28,30,33,34}$ did not corroborate this finding.

Concomitant nasal corticosteroid use, low BMI, and cumulative dose of ICS are contributing factors to the development of HPA axis suppression. ${ }^{31,32}$ Growth failure is a late finding and is not highly sensitive for detecting HPA axis suppression. ${ }^{30}$ Thus, practitioners should test most at-risk patients before growth failure occurs. However, when growth failure is detected, HPA axis function should be tested. ${ }^{22,35}$

Poor adherence to ICS treatment has a protective effect, likely due to partial recovery and incomplete suppression of the adrenal glands. ${ }^{32}$ However, poor adherence also likely conversely leads to poorer asthma control and additional oral corticosteroid doses.

Our recommendations, as summarized in Table 2 , include testing cortisol levels between 7 and 9 AM in all symptomatic patients not in crisis. If the morning cortisol level is less than $3 \mu \mathrm{g} / \mathrm{dL}$, a diagnosis of Al is made. However, if the morning cortisol level is $3 \mu \mathrm{g} / \mathrm{dL}$ or greater, an ACTH stimulation test is required. Symptoms of $\mathrm{Al}$ in patients taking ICSs are similar to those seen with other forms of ACTH insufficiency, including anorexia, weight loss, growth failure, and hypoglycemia; unique to these cases are possible signs of apparent corticosteroid excess, such as cushingoid features.

Symptoms of adrenal crisis, such as hypotension, lethargy, and hypoglycemia, should provoke immediate testing, including a cortisol level in all cases and stimulation testing when possible. If the patient is unstable or ill appearing, treatment with stress doses of corticosteroids should be prompt while awaiting results.

We also recommend testing in certain categories of asymptomatic patients taking ICSs, including those taking high daily ICS doses or an ICS with other systemically absorbed corticosteroids, particularly patients with low BMI. The 10- $\mathrm{\mu g} / \mathrm{dL}$ threshold is acknowledged by our group as somewhat arbitrary; however, it is widely used in clinical practice by endocrinologists. Referral for stimulation tests on all at-risk patients is impractical. With this in mind, high-risk patients should be monitored for symptoms of Al even with reassuring morning cortisol levels.

We acknowledge that although the 1- $\mu$ g ACTH test is not definitely superior to the standard 250- $\mu$ g ACTH stimulation test, it is generally regarded as more sensitive for secondary (central) HPA axis suppression. ${ }^{36}$ At a minimum, baseline and 30 -minute cortisol val- ues should be measured, although sampling at more frequent intervals increases testing reliability (ie, 10-, 15-, 20-, and 25-minute samples). ${ }^{37}$ A peak cortisol level below $18 \mu \mathrm{g} / \mathrm{dL}$ indicates Al. ${ }^{38}$

When HPA axis suppression from ICS use is detected in symptomatic patients, daily treatment with corticosteroids are required. In milder or asymptomatic cases, treatment may be needed only in the setting of illness or physical stress. All cases of HPA axis suppression should be referred to an endocrinologist, and these patients should follow up closely with their pulmonologist or allergist for consideration of ICS dose reduction if safe, possibly by adding a corticosteroid-sparing agent (ie, leukotriene receptor antagonists).

\section{Effects on Linear Growth}

\section{Primary Conclusions}

In most patients, ICSs have minor and short-term effects on growth and very mild but potentially persistent long-term effects (level of evidence 2) (few studies followed through to final height attainment).

\section{Primary Recommendations}

The minor growth risks are outweighed by the respiratory benefits of ICSs (grade of recommendation B). Patients at higher risk include those using additional growth-impairing medications (grade of recommendation D) (primarily based on expert opinion).

Oral corticosteroids impair linear growth through suppression of growth hormone secretion, down-regulating the growth hormone receptor, reduction of IGF-1 concentration, and suppression of collagen synthesis at the growth plate. ${ }^{39}$

The effect of ICSs on linear growth has been evaluated via knemometry, a technique that measures the distance from the surface of the right flexed knee to the bottom of the sole and is a precise method of monitoring short-term growth. ${ }^{40-42}$ A placebocontrolled, crossover trial found a reduction in growth by $32 \%$ after 2 weeks of budesonide dry powder inhaler therapy. ${ }^{41}$ Similar methods have been used to reveal growth reduction with short-term therapy with other ICSs, including fluticasone and beclomethasone dipropionate hydrofluoroalkane. ${ }^{42-44}$ Ciclesonide, thus far, has not been found to cause major growth impairment using knemometry. ${ }^{43}$

Intermediate-term investigations of the effect of ICSs on growth have found mild impairment. Using inhaled chlorofluorocarbon and beclomethasone dipropionate dry powder inhaler at $200 \mu \mathrm{g}$ twice daily, the Dutch Pediatric Asthma Study Group ${ }^{45}$ found a significant but small reduction in height $(-0.28 \mathrm{SD})$ in 1 year. A subsequent study ${ }^{46}$ found that doubling the dose of chlorofluorocarbonbeclomethasone dipropionate dry powder inhaler (400 $\mu \mathrm{g}$ twice daily) had a more significant effect on height (-0.27SD) than a standard chlorofluorocarbon-beclomethasone dipropionate dry powder inhaler dose (200 $\mu \mathrm{g}$ twice daily; -0.16 SD) for 1 year, and there was no added benefit. Of note, there was a disparity in the results at the same dose from the same group, perhaps highlighting the variable short-term effects of ICSs on growth.

In a large, prospective, open-label study of both budesonide and fluticasone, Anthracopoulos et $\mathrm{al}^{47}$ found growth reduction in both groups in the first 6 to 12 months (-0.08SD), which was consistent with previous studies. ${ }^{48,49}$ However, patients' heights returned to the baseline by 24 and 36 months. 
Adult height is arguably the most critical outcome measure of ICS suppressive effect on growth. Most long-term studies ${ }^{43,50,51}$ have found that adult heights in treated children and nontreated asthmatic control patients did not differ significantly. However, few studies ${ }^{52,53}$ have found a minor effect on final height of $1 \mathrm{~cm}$.

\section{Effects on Bone Mineral Density}

\section{Primary Conclusions}

Inhaled corticosteroids have mild effects on bone mineral density (BMD) that usually do not reach the threshold of clinical significance (level of evidence 2). Measures to ensure vitamin D sufficiency may ameliorate the negative BMD effects of ICSs (level of evidence 4).

\section{Primary Recommendations}

Routine dual-energy X-ray absorptiometry screening in children taking ICSs without other major risk factors is not indicated (grade of recommendation $B$ ). Measures to ensure vitamin D and calcium sufficiency are indicated and in lower-risk patients taking ICSs entail routine vitamin D supplementation of 400 to $800 \mathrm{IU} / \mathrm{d}$ without monitoring vitamin D levels in blood (grade of recommendation C).

Several mechanisms impair both gastrointestinal absorption tract and renal tubular reabsorption of calcium, resulting in secondary hyperparathyroidism. ${ }^{54}$ Furthermore, corticosteroids suppress gonadotropin-releasing hormone and inhibit both growth hormone and IGF-1 secretion and growth hormone and IGF-1 axis action, synergistically reducing BMD. Of note, corticosteroid-induced bone mineral loss occurs mainly in trabecular bone, such as the spine. ${ }^{39}$

The threshold dose of ICSs for bone mineral loss has not been conclusively defined. Most pediatric studies ${ }^{55-58}$ evaluated the effects of ICSs on lumbar spine BMD by dual-energy X-ray absorptiometry. A 2003 meta-analysis ${ }^{59}$ of 6 studies of adults included a total of 635 asthmatic patients using 4 different ICSs for at least 3 years. This analysis did not reveal a significant difference $(-4.1 \%, P=.80)$ in lumbar BMD in patients vs controls.

Assessment of the effects of ICSs on BMD in children is confounded by variable bone accretion associated with linear growth and age at entry into puberty. ${ }^{60}$ Several studies ${ }^{60-63}$ have looked at younger children to minimize the confounder of puberty. Three studies $^{60-62}$ found no deleterious effects of standard doses of beclomethasone or fluticasone on BMD in children 12 years and younger. However, a study ${ }^{63}$ of 48 prepubertal children using high-dose beclomethasone or budesonide (mean [SD] dose, 670 [480] $\mu \mathrm{g} / \mathrm{m}^{2}$ daily) found a dose-dependent decrease of lumbar spine BMD accrual in 1 year in treated patients; of note, those taking oral corticosteroids were not excluded, and the study did not calculate $\mathrm{Cls}$.

A study ${ }^{64}$ evaluating BMD in 37 adolescents (mean [SD] age, 13.6 [3.3] years) treated with high-dose fluticasone propionate (mean [SD] dose, 770 [250] $\mu \mathrm{g} / \mathrm{m}^{2}$ daily) for a mean (SD) of 2.9 (1.6) years revealed that lumbar BMD was more than 1 SD below the mean in $35 \%$ of treated patients compared with controls $(P=.001)$. However, when correcting for bone age, this value decreased to $16 \%$, which was no longer statistically significant.

Overall, children receiving high-dose ICSs are at risk for substantially diminished BMD if they also have concomitant risk fac- tors, such as frequent oral corticosteroids, malnutrition, or chronic disease. There is some evidence that optimizing vitamin D in children taking ICSs can ameliorate this effect. ${ }^{55,65}$ Thus, although the role of routine monitoring and titration of vitamin D supplementation is not yet established, our group considers it advisable for this group at highest risk.

For those taking ICSs without a compounding risk, routine serum vitamin $D$ level determination is not needed. Clinicians should be cognizant of adequate vitamin $D$ intake, prophylactically provide 400 to $800 \mathrm{IU} / \mathrm{d}$ of vitamin $\mathrm{D}$, and ensure adequate dietary calcium of 1000 to $1300 \mathrm{mg} / \mathrm{d}^{66}$

\section{Effects of Inhaled Corticosteroids on Glucose Metabolism}

\section{Primary Conclusions}

The effects of ICSs on glucose levels are dose dependent. The effects of ICSs on glucose levels are primarily of concern in patients who have a previous diagnosis of DM or are at high risk of type 2 DM. These 2 conclusions are of evidence level 4 primarily because pediatric studies are limited. Data from adults in these areas are stronger.

\section{Primary Recommendations}

Patients with DM in whom ICSs are initiated or increased may require changes to their DM medication regimen. Patients at high risk of developing type 2 DM from obesity compounded by another risk factor, such as ethnicity and/or a positive family history, should be tested after ICS treatment is initiated or increased. Testing for DM is generally recommended for this population regardless of whether they are taking ICSs (grade of recommendation $\mathrm{D}$ ). These recommendations are primarily regarded as expert opinion because pediatric studies are limited, although adult data are stronger.

The metabolic effects of corticosteroids include decreased insulin sensitivity in several tissues. ${ }^{67}$ The decrease in insulinstimulated glucose uptake in skeletal muscle is mediated through glucocorticoid-induced postreceptor effects. ${ }^{68}$ Corticosteroids also cause an increase in hepatic glucose production ${ }^{69}$ as reported by Pagano et $\mathrm{al}^{7 \mathrm{O}}$; under the influence of treatment with high-dose glucocorticoid, there was an increase in hepatic glucose production evident in both the fasted and postprandial states. However, this glucogenic effect of corticosteroids could be overcome by high concentrations of insulin, whereas skeletal muscle glucose uptake was diminished. Therefore, peripheral insulin resistance appears to be the predominant mechanism leading to corticosteroid-induced hyperglycemia. It has also been suggested that islet cell toxic effects and apoptosis occur in patients exposed to corticosteroids. ${ }^{71}$ Furthermore, corticosteroids are known to inhibit insulin secretion by pancreatic $\beta$-cells. ${ }^{72}$

Inhaled corticosteroids have been implicated in contributing to clinical hyperglycemia and DM. Most studies examining this effect have been conducted in adult populations. For example, a study ${ }^{69}$ performed in a large Veterans Affairs population suggested that, although ICSs were not associated with hyperglycemia in individuals without DM, among people with DM, ICS use was correlated with glucose levels in a dose-dependent manner. A 


\begin{tabular}{|c|c|c|c|c|c|c|c|c|c|}
\hline \multirow[b]{3}{*}{ Corticosteroid } & \multicolumn{9}{|c|}{ Daily Dose by Age, y } \\
\hline & \multicolumn{3}{|l|}{ Low } & \multicolumn{3}{|l|}{ Medium } & \multicolumn{3}{|l|}{ High } \\
\hline & $0-4$ & $5-11$ & $\begin{array}{l}>12 \text { to } \\
\text { Adults }\end{array}$ & $0-4$ & $5-11$ & $\begin{array}{l}>12 \text { to } \\
\text { Adults }\end{array}$ & $0-4$ & $5-11$ & $\begin{array}{l}>12 \text { to } \\
\text { Adults }\end{array}$ \\
\hline $\begin{array}{l}\text { Beclomethasone dipropionate } \\
\text { hydrofluoroalkane } \\
\text { ( } 40 \text { or } 80 \mu \mathrm{g} \text { per puff), } \mu \mathrm{g}\end{array}$ & NA & $80-160$ & $80-240$ & NA & $>160-320$ & $>240-480$ & NA & $>320$ & $>480$ \\
\hline \multicolumn{10}{|l|}{ Budesonide } \\
\hline $\begin{array}{l}\text { DPI }(90,180 \text {, or } \\
200 \mu g), \mu g\end{array}$ & NA & $180-400$ & $180-600$ & NA & $>400-800$ & $<600-1200$ & NA & $>800$ & $>1200$ \\
\hline $\begin{array}{l}\text { Inhaled (inhaled } \\
\text { suspension), mg }\end{array}$ & $0.25-0.5$ & 0.5 & NA & $>0.5-1.0$ & 1.0 & NA & $>1.0$ & 2.0 & NA \\
\hline \multicolumn{10}{|l|}{ Funisolide } \\
\hline $\begin{array}{l}\text { Standard }(250 \mu \mathrm{g} \\
\text { per puff }), \mu \mathrm{g}\end{array}$ & NA & $500-750$ & $500-1000$ & NA & $1000-1250$ & $>1000-2000$ & NA & $>1250$ & $\geq 2000$ \\
\hline $\begin{array}{l}\text { Hydrofluoroalkane } \\
(80 \mu \mathrm{g} \text { per puff), } \mu \mathrm{g}\end{array}$ & NA & 160 & 320 & NA & 320 & $>320-640$ & NA & $\geq 640$ & $\geq 640$ \\
\hline \multicolumn{10}{|l|}{ Fluticasone dipropionate } \\
\hline $\begin{array}{l}\text { Hydrofluoroalkane/MDI ( } 44, \\
110, \text { or } 220 \mu \mathrm{g} \text { per puff), } \mu \mathrm{g}\end{array}$ & 176 & $88-176$ & $88-264$ & $>176-352$ & $>176-352$ & $>264-440$ & $>352 \mathrm{mcg}$ & $>176-352$ & $>440$ \\
\hline $\begin{array}{l}\mathrm{DPI}(50,100, \text { or } 250 \mu \mathrm{g} \\
\text { per puff), } \mu \mathrm{g}\end{array}$ & NA & $100-200$ & $100-300$ & NA & $>200-400$ & $>300-500$ & NA & $>200-400$ & $>500$ \\
\hline Mometasone DPI $(220 \mu \mathrm{g}), \mu \mathrm{g}$ & NA & NA & 200 & NA & NA & 400 & NA & NA & $<400$ \\
\hline Triamcinolone acetonide & NA & $300-600$ & $300-750$ & NA & $>600-900$ & $>750-1500$ & NA & $>600-900$ & $>1500$ \\
\hline
\end{tabular}

Abbreviations: DPI, dry powder inhaler; MDI, metered-dose inhaler; NA, not applicable because not approved, not available, no data available, or safety and efficacy not established in this age group.

number of small studies of adults ${ }^{73,74}$ have similarly linked hyperglycemia among diabetic individuals, but not individuals without DM, to ICS use.

Of note, a number of investigations ${ }^{75,76}$ have suggested that ICSS can induce insulin resistance among individuals without DM. A large epidemiologic study ${ }^{77}$ from Canada identified a $34 \%$ to $64 \%$ higher incidence of new-onset DM among those taking ICSs, as well as a 34\% to $54 \%$ higher rate of progression to insulin use among patients with established DM taking ICSs, although the researchers did not adjust for BMI. Both these studies established a dose-response association between ICS and blood glucose levels, with daily doses in excess of $1000 \mu \mathrm{g}$ of fluticasone propionate dry powder inhaler having the most pronounced effect.

The only pediatric study ${ }^{78}$ to date examining glycemic effects of ICSs reported a small but statistically significant increase in hemoglobin $A_{1 c}$ levels in children with asthma who were taking ICSs. However, the study failed to identify a dose-response association between ICSs and glucose levels. Furthermore, the only study ${ }^{79}$ to examine the effects of asthma treatment on children with preexisting DM contained an insufficient number treated with ICSs to draw meaningful conclusions.

Our recommendations with regard to the effects of ICSs on glucose metabolism are summarized in Table 2. They include adjusting DM medications as needed when ICS use is initiated or ad- justed. For children without DM, our recommendations include testing those at risk because of obesity compounded by an additional factor, such as high-risk ethnic group or family history of type $2 \mathrm{DM}$. Evidence about levels of fasting glucose and hemoglobin $\mathrm{A}_{1 \mathrm{c}}$ thresholds placing children into a higher DM risk category continues to be a point of debate; however, our team has chosen a fasting glucose level of $100 \mathrm{mg} / \mathrm{dL}$ and a hemoglobin $\mathrm{A}_{1 \mathrm{c}}$ level of $6.0 \%$ based on available data. ${ }^{80,81}$

\section{Conclusions}

Inhaled corticosteroids are generally safe, effective drugs, but adverse endocrine effects may occur. Although adverse effects and the thresholds defined as high dose by asthma guidelines do not precisely correlate, for the sake of clinical practice, high dose for any particular compound is similar to that defined by the National Asthma Education and Prevention Program. ${ }^{82}$ We summarize dosing guidelines in Table 3. We agree with the step-up and step-down approach put forth in these guidelines, ${ }^{82}$ meaning that patients with poor asthma control need an increase in dosing, followed by reductions in dosing when adequate asthma control is achieved. We do not recommend decreasing the ICS dose if it is deemed necessary to prevent pulmonary exacerbations and recurrent treatment with oral corticosteroids.

\section{ARTICLE INFORMATION}

Accepted for Publication: September 20, 2015.

Published Online: December 21, 2015 doi:10.1001/jamapediatrics.2015.3526.
Author Affiliations: Phoenix Children's Hospital, Phoenix, Arizona (Kapadia); Riley Hospital for Children, Indiana University School of Medicine, Indianapolis (Nebesio); Department of Pediatrics, St Louis University, Cardinal Glennon Children's Hospital, St Louis, Missouri (Myers); Children's
Hospital of Philadelphia, Philadelphia, Pennsylvania (Willi); University of Minnesota Masonic Children's Hospital, Minneapolis (Miller); Department of Pediatrics, University of Wisconsin School of Medicine and Public Health, Madison (Allen); Division of Pediatric Endocrinology, Department of 
Pediatrics, Maimonides Medical Center, Brooklyn, New York (Jacobson-Dickman).

Author Contributions: Dr Jacobson-Dickman had full access to all the data in the study and takes responsibility for the integrity of the data and the accuracy of the data analysis.

Study concept and design: Kapadia, Nebesio, Myers, Willi, Jacobson-Dickman.

Acquisition, analysis, or interpretation of data: Kapadia, Myers, Willi, Miller, Allen.

Drafting of the manuscript: Kapadia, Nebesio,

Myers, Willi, Miller, Jacobson-Dickman.

Critical revision of the manuscript for important intellectual content: Kapadia, Nebesio, Myers, Willi, Miller, Allen.

Administrative, technical, or material support: Kapadia, Myers, Willi.

Study supervision: Kapadia, Nebesio, Willi, Allen, Jacobson-Dickman.

Conflict of Interest Disclosures: None reported.

Group Information: The members of the Pediatric Endocrine Society Drug and Therapeutics Committee are Preneet Brar, MD, Mark D. DeBoer, MD, Patricia Fechner, MD, Rubina Heptulla, MD, Ryan Miller, MD, Deborah Mitchell, MD, Kathleen Moltz, MD, Sripriya Raman, MD, Takara Stanley, MD, Naveen Uli, MD, and Maria Vogiatzi, MD.

Additional Contributions: We thank the Board of Directors of the Pediatric Endocrine Society for their oversight, review, and approval of the manuscript and in particular John S. Fuqua, MD, and Mitchel Geffner, MD, for their guidance.

\section{REFERENCES}

1. Hübner M, Hochhaus G, Derendorf H. Comparative pharmacology, bioavailability, pharmacokinetics, and pharmacodynamics of inhaled glucocorticosteroids. Immunol Allergy Clin North Am. 2005;25(3):469-488

2. Zöllner EW. Hypothalamic-pituitary-adrenal axis suppression in asthmatic children on inhaled corticosteroids (part 2)-the risk as determined by gold standard adrenal function tests: a systematic review. Pediatr Allergy Immunol. 2007;18(6):469-474.

3. Johnson M. Pharmacodynamics and pharmacokinetics of inhaled glucocorticoids. J Allergy Clin Immunol. 1996;97(1, pt 2):169-176.

4. Barnes NC. The properties of inhaled corticosteroids: similarities and differences. Prim Care Respir J. 2007;16(3):149-154.

5. Randell TL, Donaghue KC, Ambler GR, Cowell CT, Fitzgerald DA, van Asperen PP. Safety of the newer inhaled corticosteroids in childhood asthma. Paediatr Drugs. 2003;5(7):481-504.

6. Kannisto S, Korppi M, Remes K, Voutilainen R. Adrenal suppression, evaluated by a low dose adrenocorticotropin test, and growth in asthmatic children treated with inhaled steroids. $J$ Clin Endocrinol Metab. 2000;85(2):652-657.

7. Allen DB. Inhaled corticosteroids and growth: still an issue after all these years. J Pediatr. 2015;166 (2):463-469.

8. Dempsey OJ, Wilson AM, Coutie WJ, Lipworth BJ. Evaluation of the effect of a large volume spacer on the systemic bioactivity of fluticasone propionate metered-dose inhaler. Chest. 1999;116 (4):935-940.

9. Nair A, Menzies D, Hopkinson P, McFarlane L, Lipworth BJ. In vivo comparison of the relative systemic bioavailability of fluticasone propionate from three anti-static spacers and a metered dose inhaler. Br J Clin Pharmacol. 2009;67(2):191-198.

10. Martin RJSS, Szefler SJ, Chinchilli VM, et al. Systemic effect comparisons of six inhaled corticosteroid preparations. Am J Respir Crit Care Med. 2002;165(10):1377-1383.

11. Minto C, Li B, Tattam B, Brown K, Seale JP, Donnelly R. Pharmacokinetics of epimeric budesonide and fluticasone propionate after repeat dose inhalation: intersubject variability in systemic absorption from the lung. $\mathrm{Br} J \mathrm{Clin}$ Pharmacol. 2000;50(2):116-124

12. Brutsche MH, Brutsche IC, Munawar M, et al. Comparison of pharmacokinetics and systemic effects of inhaled fluticasone propionate in patients with asthma and healthy volunteers: a randomised crossover study. Lancet. 2000;356(9229):556-561.

13. Todd GR, Acerini CL, Ross-Russell R, Zahra $S$, Warner JT, McCance D. Survey of adrenal crisis associated with inhaled corticosteroids in the United Kingdom. Arch Dis Child. 2002;87(6):457-461.

14. Ahmet $A$, Kim H, Spier S. Adrenal suppression: a practical guide to the screening and management of this under-recognized complication of inhaled corticosteroid therapy. Allergy Asthma Clin Immunol. 2011;7(7):13.

15. Mortimer KJ, Tata LJ, Smith CJ, et al. Oral and inhaled corticosteroids and adrenal insufficiency: a case-control study. Thorax. 2006;61(5):405-408.

16. Fraser CG, Preuss FS, Bigford WD. Adrenal atrophy and irreversible shock associated with cortisone therapy. J Am Med Assoc. 1952;149(17): 1542-1543.

17. Russell G. Inhaled corticosteroid therapy in children: an assessment of the potential for side effects. Thorax. 1994;49(12):1185-1188.

18. Dluhy RG. Clinical relevance of inhaled corticosteroids and HPA axis suppression. J Allergy Clin Immunol. 1998;101(4 Pt 2):S447-S450.

19. Goldstein DE, König P. Effect of inhaled beclomethasone dipropionate on hypothalamic-pituitary-adrenal axis function in children with asthma. Pediatrics. 1983;72(1):60-64.

20. Katsunuma T, Akasawa A, likura Y. Adrenal function of children with bronchial asthma treated with beclomethasone dipropionate. Ann Allergy. 1992:69(6):529-532.

21. Lipworth BJ. Systemic adverse effects of inhaled corticosteroid therapy: a systematic review and meta-analysis. Arch Intern Med. 1999;159(9): 941-955.

22. Patel L, Wales JK, Kibirige MS, Massarano AA Couriel JM, Clayton PE. Symptomatic adrenal insufficiency during inhaled corticosteroid treatment. Arch Dis Child. 2001;85(4):330-334.

23. Drake AJ, Howells RJ, Shield JPH, Prendiville A, Ward PS, Crowne EC. Symptomatic adrenal insufficiency presenting with hypoglycaemia in children with asthma receiving high dose inhaled fluticasone propionate. BMJ. 2002;324(7345) 1081-1082.

24. Zöllner EW. Hypothalamic-pituitary-adrenal axis suppression in asthmatic children on inhaled corticosteroids, part 1: which test should be used? Pediatr Allergy Immunol. 2007;18(5):401-409.
25. Meakin JW, Grabbé J, Bayles TB, Nelson DH Pituitary-adrenal function following long-term steroid therapy. Am J Med. 1960;29(3):459-464.

26. Molimard M, Girodet PO, Pollet $\mathrm{C}$, et al. Inhaled corticosteroids and adrenal insufficiency: prevalence and clinical presentation. Drug Saf. 2008;31(9):769-774.

27. Zöllner EW. Hypothalamic-pituitary-adrenal axis suppression in asthmatic children on inhaled corticosteroids (Part 2)--the risk as determined by gold standard adrenal function tests: a systematic review. Pediatr Allergy Immunol. 2007:18(6):469-474.

28. Klein $\mathrm{R}$, Waldman $\mathrm{D}$, Kershnar $\mathrm{H}$, et al. Treatment of chronic childhood asthma with beclomethasone dipropionate aerosol, I: a double-blind crossover trial in nonsteroid dependent patients. Pediatrics. 1977;60(1):7-13.

29. Vaz R, Senior B, Morris M, Binkiewicz A. Adrenal effects of beclomethasone inhalation therapy in asthmatic children. J Pediatr. 1982;100 (4):660-662.

30. Zöllner EWLC, Lombard CJ, Galal U, Hough S, Irusen EM, Weinberg E. Screening for hypothalamic-pituitary-adrenal axis suppression in asthmatic children remains problematic: a cross-sectional study. BMJ Open. 2013;3(8): e002935.

31. Zöllner EWLC, Lombard C, Galal U, Hough $S$, Irusen E, Weinberg E. Hypothalamic-pituitaryadrenal axis suppression in asthmatic children on inhaled and nasal corticosteroids: more common than expected? J Pediatr Endocrinol Metab. 2011;24 (7-8):529-534.

32. Zöllner EWLC, Lombard CJ, Galal U, Hough FS, Irusen EM, Weinberg E. Hypothalamic-pituitaryadrenal axis suppression in asthmatic school children. Pediatrics. 2012;130(6):e1512-e1519.

33. Kamps AW, Molenmaker M, Kemperman R, van der Veen BS, Bocca G, Veeger NJ. Children with asthma have significantly lower long-term cortisol levels in their scalp hair than healthy children. Acta Paediatr. 2014;103(9):957-961.

34. Zöllner EW, Lombard $C$, Galal $U$, Hough $S$, Irusen E, Weinberg E. Hypothalamic-pituitaryadrenal axis suppression in asthmatic children on inhaled and nasal corticosteroids: is the early-morning serum adrenocorticotropic hormone (ACTH) a useful screening test? Pediatr Allergy Immunol. 2011;22(6):614-620.

35. Todd G, Dunlop K, McNaboe J, Ryan MF, Carson D, Shields MD. Growth and adrenal suppression in asthmatic children treated with high-dose fluticasone propionate. Lancet. 1996;348(9019): 27-29.

36. Kazlauskaite R, Evans AT, Villabona CV, et al; Consortium for Evaluation of Corticotropin Test in Hypothalamic-Pituitary Adrenal Insufficiency. Corticotropin tests for hypothalamic-pituitaryadrenal insufficiency: a metaanalysis. J Clin Endocrinol Metab. 2008;93(11):4245-4253.

37. Crowley S, Hindmarsh PC, Holownia P, Honour JW, Brook CGD. The use of low doses of ACTH in the investigation of adrenal function in man. J Endocrinol. 1991;130(3):475-479.

38. Kazlauskaite R, Maghnie M. Pitfalls in the diagnosis of central adrenal insufficiency in children. Endocr Dev. 2010;17:96-107. 
39. Allen DB. Effects of inhaled steroids on growth, bone metabolism, and adrenal function. Adv Pediatr. 2006:53:101-110.

40. Wolthers OD. Methodology and implications of knemometry in growth assessment of inhaled glucocorticoids. Pediatr Allergy Immunol. 2010; 21(1, pt 2):e190-e198.

41. Wolthers OD, Walters EG. Short-term lower leg growth in 5- to 11-year-old asthmatic children using beclomethasone dipropionate inhalers with chlorofluorocarbon or hydrofluoroalkane propellants: a 9-week, open-label, randomized, crossover, noninferiority study. Clin Ther. 2011;33 (8):1069-1076.

42. Wolthers OD, Pedersen S. Short-term growth during treatment with inhaled fluticasone propionate and beclomethasone dipropionate. Arch Dis Child. 1993;68(5):673-676.

43. Agertoft L, Pedersen S. Lower-leg growth rates in children with asthma during treatment with ciclesonide and fluticasone propionate. Pediat Allergy Immunol. 2010;21(1 Pt 2):e199-e205.

44. Doull IJ, Freezer NJ, Holgate ST. Growth of prepubertal children with mild asthma treated with inhaled beclomethasone dipropionate. Am J Respir Crit Care Med. 1995;151(6):1715-1719.

45. Verberne AA, Frost C, Roorda RJ, van der Laag $\mathrm{H}$, Kerrebijn KF; The Dutch Paediatric Asthma Study Group. One year treatment with salmeterol compared with beclomethasone in children with asthma. Am J Respir Crit Care Med. 1997;156(3, pt 1) 688-695.

46. Verberne AA, Frost C, Duiverman EJ, Grol MH, Kerrebijn KF; The Dutch Asthma Study Group. Addition of salmeterol versus doubling the dose of beclomethasone in children with asthma. Am J Respir Crit Care Med. 1998;158(1):213-219.

47. Anthracopoulos MB, Papadimitriou A, Panagiotakos DB, et al. Growth deceleration of children on inhaled corticosteroids is compensated for after the first 12 months of treatment. Pediatr Pulmonol. 2007:42(5):465-470.

48. Saha MT, Laippala P, Lenko HL. Growth of asthmatic children is slower during than before treatment with inhaled glucocorticoids. Acta Paediatr. 1997;86(2):138-142.

49. The Childhood Asthma Management Program Research Group. Long-term effects of budesonide or nedocromil in children with asthma. N Engl J Med. 2000;343(15):1054-1063.

50. Hoover RMEJ, Erramouspe J, Bell EA Cleveland KW. Effect of inhaled corticosteroids on long-term growth in pediatric patients with asthma and allergic rhinitis. Ann Pharmacother. 2013;47(9): 1175-1181.

51. Arend EEFG, Fischer GB, Debiasi M, Schmid H. Inhaled corticosteroid treatment and growth of asthmatic children seen at outpatient clinics. J Pediatr (Rio J). 2006;82(3):197-203.

52. Kelly HW, Sternberg AL, Lescher R, et al; CAMP Research Group. Effect of inhaled glucocorticoids in childhood on adult height. N Engl J Med. 2012;367 (10):904-912.

53. Raissy HH, Blake K. Does use of inhaled corticosteroid for management of asthma in children make them shorter adults? Pediatr Allergy Immunol Pulmonol. 2013:26(2):99-101.
54. Skversky AL, Kumar J, Abramowitz MK, Kaskel FJ, Melamed ML. Association of glucocorticoid use and low 25 -hydroxyvitamin D levels: results from the National Health and Nutrition Examination Survey (NHANES): 2001-2006. J Clin Endocrinol Metab. 2011;96(12): 3838-3845.

55. Tse SMKH, Kelly HW, Litonjua AA, Van Natta ML, Weiss ST, Tantisira KG; Childhood Asthma Management Program Research Group. Corticosteroid use and bone mineral accretion in children with asthma: effect modification by vitamin D. J Allergy Clin Immunol. 2012;130(1): 53-60.e4.

56. Turpeinen M, Pelkonen AS, Nikander K, et al. Bone mineral density in children treated with daily or periodical inhaled budesonide: the Helsinki Early Intervention Childhood Asthma study. Pediatr Res. 2010;68(2):169-173.

57. Harris M, Hauser S, Nguyen TV, et al. Bone mineral density in prepubertal asthmatics receiving corticosteroid treatment. J Paediatr Child Health. 2001;37(1):67-71.

58. Kelly HW, Van Natta ML, Covar RA, Tonascia J, Green RP, Strunk RC; CAMP Research Group. Effect of long-term corticosteroid use on bone mineral density in children: a prospective longitudinal assessment in the childhood Asthma Management Program (CAMP) study. Pediatrics. 2008;122(1) e53-e61.

59. Sharma PK, Malhotra S, Pandhi P, Kumar N. Effect of inhaled steroids on bone mineral density: a meta-analysis. J Clin Pharmacol. 2003;43(2): 193-197.

60. Gregson RK, Rao R, Murrills AJ, Taylor PA, Warner JO. Effect of inhaled corticosteroids on bone mineral density in childhood asthma: comparison of fluticasone propionate with beclomethasone dipropionate. Osteoporos Int. 1998;8(5):418-422.

61. Rao R, Gregson RK, Jones AC, Miles EA, Campbell MJ, Warner JO. Systemic effects of inhaled corticosteroids on growth and bone turnover in childhood asthma: a comparison of fluticasone with beclomethasone. Eur Respir J. 1999:13(1):87-94

62. Altintas DU, Karakoc GB, Can S, Yilmaz M Kendirli SG. The effects of long term use of inhaled corticosteroids on linear growth, adrenal function and bone mineral density in children. Allergol Immunopathol (Madr). 2005;33(4):204-209.

63. Allen HD, Thong IG, Clifton-Bligh $P$, Holmes $S$, Nery L, Wilson KB. Effects of high-dose inhaled corticosteroids on bone metabolism in prepubertal children with asthma. Pediatr Pulmonol. 2000:29 (3):188-193.

64. Griffiths AL, Sim D, Strauss B, Rodda C Armstrong D, Freezer N. Effect of high-dose fluticasone propionate on bone density and metabolism in children with asthma. Pediatr Pulmonol. 2004;37(2):116-121.

65. Weldon D. The effects of corticosteroids on bone growth and bone density. Ann Allergy Asthma Immunol. 2009:103(1):3-11.

66. Abrams SA. Dietary guidelines for calcium and vitamin D: a new era. Pediatrics. 2011;127(3):566-568. 67. Turpeinen M, Sorva R, Juntunen-Backman K. Changes in carbohydrate and lipid metabolism in children with asthma inhaling budesonide. J Allergy Clin Immunol. 1991;88(3 Pt 1):384-389.

68. Willi SM, Kennedy A, Wallace P, Ganaway E, Rogers NL, Garvey WT. Troglitazone antagonizes metabolic effects of glucocorticoids in humans: effects on glucose tolerance, insulin sensitivity, suppression of free fatty acids, and leptin. Diabetes 2002;51(10):2895-2902.

69. Slatore CG, Bryson CL, Au DH. The association of inhaled corticosteroid use with serum glucose concentration in a large cohort. Am J Med. 2009 122(5):472-478.

70. Pagano G, Cavallo-Perin $\mathrm{P}$, Cassader M, et al An in vivo and in vitro study of the mechanism of prednisone-induced insulin resistance in healthy subjects. J Clin Invest. 1983;72(5):1814-1820.

71. Ranta F, Avram D, Berchtold S, et al. Dexamethasone induces cell death in insulin-secreting cells, an effect reversed by exendin-4. Diabetes. 2006;55(5):1380-1390. 72. Lambillotte C, Gilon P, Henquin JC. Direct glucocorticoid inhibition of insulin secretion. An in vitro study of dexamethasone effects in mouse islets. J Clin Invest. 1997;99(3):414-423.

73. Faul JL, Wilson SR, Chu JW, Canfield J, Kuschner WG. The effect of an inhaled corticosteroid on glucose control in type 2 diabetes. Clin Med Res. 2009;7(1-2):14-20.

74. O'Byrne PM, Rennard S, Gerstein $\mathrm{H}$, et al. Risk of new onset diabetes mellitus in patients with asthma or COPD taking inhaled corticosteroids. Respir Med. 2012;106(11):1487-1493.

75. Kiviranta K, Turpeinen M. Effect of eight months of inhaled beclomethasone dipropionate and budesonide on carbohydrate metabolism in adults with asthma. Thorax. 1993;48(10):974-978.

76. Kruszynska YT, Greenstone M, Home PD, Cooke NJ. Effect of high dose inhaled beclomethasone dipropionate on carbohydrate and lipid metabolism in normal subjects. Thorax. 1987; 42(11):881-884

77. Suissa S, Kezouh A, Ernst P. Inhaled corticosteroids and the risks of diabetes onset and progression. Am J Med. 2010;123(11):1001-1006.

78. Yucel $O$, Eker Y, Nuhoglu $C$, Ceran $O$. Hemoglobin a1c levels in children with asthma using low dose inhaled corticosteroids. Indian Pediatr. 2009:46(4):300-303.

79. Wright NP, Wales JK. The incidence of hypoglycaemia in children with type 1 diabetes and treated asthma. Arch Dis Child. 2003;88(2):155-156.

80. Shah S, Kublaoui BM, Oden JD, White PC Screening for type 2 diabetes in obese youth. Pediatrics. 2009;124(2):573-579.

81. Kapadia CR. Are the ADA hemoglobin A(1c) criteria relevant for the diagnosis of type 2 diabetes in youth? Curr Diab Rep. 2013;13(1):51-55.

82. National Asthma Education and Prevention Program. Expert Panel Report 3 (EPR-3): Guidelines for the Diagnosis and Management of Asthma-Summary Report 2007. J Allergy Clin Immunol. 2007;120(5 suppl):S94-S138. 